\title{
Congenital Langerhans cell histiocytosis in a healthy neonate having isolated cutaneous involvement with unusual rapid progression
}

\author{
Sri Lanka Journal of Child Health, 2020; 49(2): 190-192 \\ DOI: http://dx.doi.org/10.4038/sljch.v49i2.8973 \\ (Key words: Histiocytosis, newborn, Langerin, multisystem)
}

*Vinod Muniyappa ${ }^{1}$, Purnima Samayam ${ }^{1}$, Mallikarjuna Patil $^{1}$, Suma Narayan ${ }^{2}$

\section{Case report}

A female baby with a birth weight of $3250 \mathrm{~g}$ was delivered by caesarean section at 39 weeks of gestation to a healthy 24 year old mother. At birth, the baby had multiple dark coloured papules of varying sizes all over the body and a few showed central necrosis. It was a non-consanguineous marriage, and there were no similar complaints or unexplained deaths in the family.

On examination, baby was active with normal vital signs. Head to toe examination was normal except for papulo-nodular skin lesions, a few with central necrosis, scattered over face, extremities, buttocks and trunk (Figure 1). No mucosal lesions were present. The systemic examination was normal without hepatosplenomegaly or lymph node enlargement. Baby was empirically started on

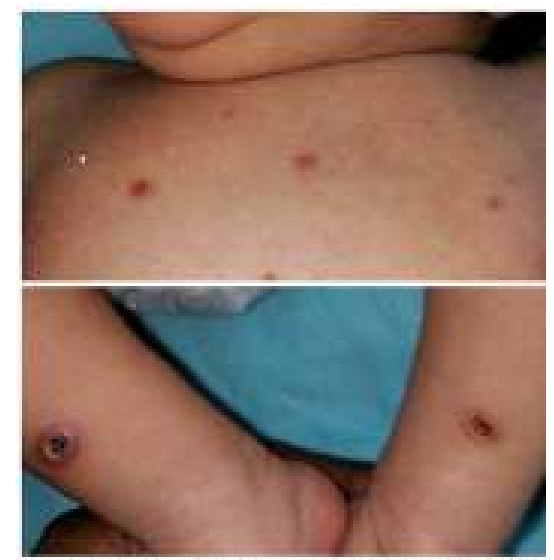

Figure 1: Papulo-nodular skin lesions

${ }^{1} B G S$ Global Institute of Medical Sciences, Bangalore, India, ${ }^{2}$ Kidwai Memorial Institute of Oncology, Bangalore, India

*Correspondence: vinodvin7777@gmail.com

(iD)

orcid.org/ 0000-0001-6547-0538

(Received on 21 September 2018: Accepted after revision on 01 November 2018)

The authors declare that there are no conflicts of interest

Personal funding was used for the project.

Open Access Article published under the Creative Commons Attribution CC-BY (CC) (P) intravenous co-amoxiclav and topical mupirocin. Blood test showed a haemoglobin level of $19.8 \mathrm{~g} / \mathrm{dl}$ and a total white blood cell count of $21,000 /$ microlitre. The differential count was $\mathrm{N}$ $45 \%$, L 36\%, M 4\%. Platelet count was $300 \mathrm{x}$ $10^{3} /$ microlitre. C-reactive protein and blood culture were negative. Liver function tests (LFTs) and renal function tests (RFTs) were normal. Ultrasound scan of brain and abdomen were normal. TORCH profile was negative. Ophthalmologic evaluation was normal.

Skin biopsy showed clusters of histiocytes with intranuclear grooving admixed with neutrophils and lymphocytes. Few cells had clear cytoplasm giving foamy appearance with few cells extending up to epidermis. Immuno-histochemistry (IHC) revealed surface CD1a positivity and cytoplasm \& nuclear positivity for S100 suggestive of congenital Langerhans cell disease- suspected congenital selfhealing reticulo-histiocytosis variant of Langerhans cell histiocytosis $(\mathrm{LCH})$.

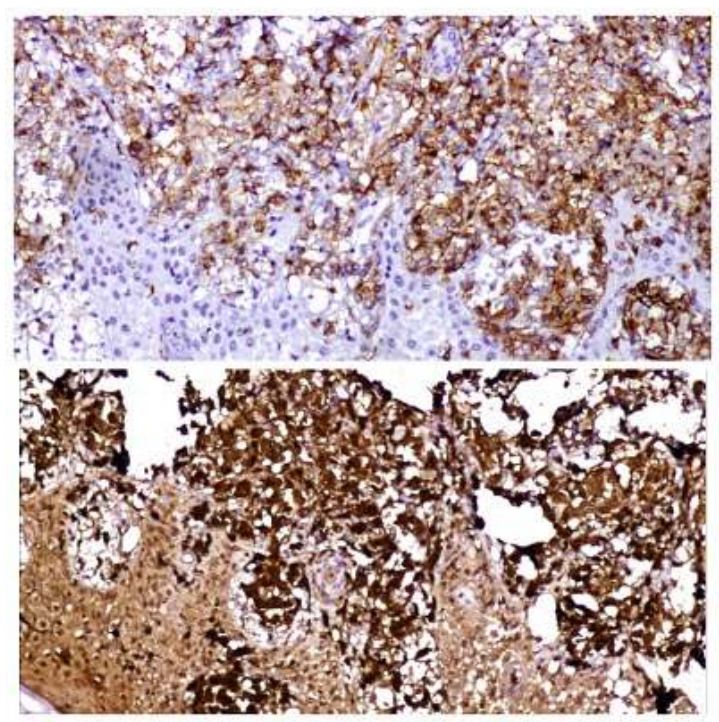

Figure 2: Skin biopsy findings

Baby was discharged on day 6 and advised to come for follow up. On first follow up on day 15, baby was alert with good weight gain. Baby had a few skin lesions in the stage of crusting and central necrosis; systemic examination was within normal limits. At 4 weeks of age baby was brought with complaints of swelling in neck and groin region; on 
examination, baby had cervical and inguinal lymphadenopathy, hepatomegaly $4 \mathrm{~cm}$ firm and few fresh papulo-vesicular skin lesions. Since baby showed progression of lesions with features of systemic involvement, baby was referred to the oncology centre for further management.

At referral centre baby was evaluated; Complete blood count $(\mathrm{CBC})$ showed a hemoglobin level of $10.6 \mathrm{~g} / \mathrm{dl}$, White blood cell count was $14,800 /$ microlitre, differential count was N $63 \%$, L $28 \%$. LFT, electrolytes and RFT were within normal limits. Ultrasound scan of abdomen showed hypoechoic lesions in both lobes of liver. Infantogram revealed miliary mottling in bilateral lung fields, widening of superior mediastinum and small osteolytic lesion in skull suggestive of LCH. Baby was started on steroids and advised admission for starting chemotherapy. However admission was denied by parents and baby was taken home. Patient attenders brought the baby to referral unit after one month with breathlessness and severe shock. Resuscitation was done but baby could not be revived.

\section{Discussion \\ Diagnosis of LCH is based on a histologic and immune-phenotypic examination of tissue. The main feature is the morphological identification of characteristic Langerhans cell; immune- histochemical studies showing positive staining of lesional cells with CD1a, langerin or both are needed for definitive diagnosis ${ }^{1}$.}

LCH can occur at any age; A higher incidence rate of 8.9 persons per million is seen in children below 15 years of age ${ }^{2}$. The incidence in neonates is about 1-2 per million ${ }^{3}$. Compared to adults, children usually have a more aggressive clinical course that requires systemic chemotherapy.

Typical cutaneous lesion of LCH manifests as a scaly, erythematous seborrhea like eruption of brown to red papules ${ }^{4}$. Neonates commonly show maculopapular red, haemorrhagic vesiculopustular lesions with or without central necrosis as seen in our case, which can be easily mistaken for an infectious process.

Pan JR et al reported and reviewed 3 cases of neonates with $\mathrm{LCH}$. They reported that any cutaneous involvement in neonates with $\mathrm{LCH}$ may indicate aggressive multi-systemic disease with poor prognosis. They reported a neonate with $\mathrm{LCH}$ with only skin involvement who insidiously developed multisystem involvement after three months of age ${ }^{5}$. Our case initially had only skin involvement which progressed rapidly to multisystem involvement. This makes it likely that neonatal LCH should be treated as multisystem disease irrespective of patient's initial presentation. In contrast, Aggarwal et al reported a 4 month old infant with nodular cutaneous lesions since birth and a past history suggestive of lung involvement. They reported spontaneous resolution of pulmonary and cutaneous lesions with absence of signs of systemic involvement, consistent with a diagnosis of congenital self-healing $\mathrm{LCH}^{6}$.

Newborns with LCH at birth with only skin lesions should be frequently monitored for systemic involvement. Chemotherapy should be started as early as possible when signs of systemic involvement are seen. As seen in the cases reported by Pan JR et al and in our case, the initial presentation of a thriving neonate with cutaneous LCH lesions only, may progress aggressively to multi-systemic involvement. Early chemotherapy should be considered for such neonates to control the disease and improve outcome.

\section{References}

1. Grana N. Langerhans cell histiocytosis. Cancer Control 2014; 21(4):328-34. https://doi.org/10.1177/107327481402100 409

PMid: 25310214

2. Stalemark H, Laurencikas E, Karis J, Gavhed D, Fadeel B, Henter JI. Incidence of Langerhans cell histiocytosis in children: A population-based study. Pediatric Blood \& Cancer 2008; 51(1):7681.

https://doi.org/10.1002/pbc.21504

PMid: 18266220

3. Minkov M, Prosch H, Steiner M, Grois N, Pötschger U, Kaatsch P, et al. Langerhans cell histiocytosis in neonates. Pediatric Blood \& Cancer 2005; 45(6):802-7. https://doi.org/10.1002/pbc.20362 PMid: 15770639

4. Stein SL, Paller AS, Haut PR, Mancini AJ. Langerhans cell histiocytosis presenting in the neonatal period: a retrospective case series. Archives of Pediatrics \& Adolescent Medicine 2001; 155(7):778-83.

https://doi.org/10.1001/archpedi.155.7.778

5. Pan JR, Yuan TM, Chen LH, Yu HM. Case Report Langerhans Cell Histiocytosis in a neonate presenting with skin-only disease: Case Report and Review of the Chinese Literature. Hong Kong Journal of Paediatrics (new series) 2014; 19(2):96-9. 
6. Aggarwal V, Seth A, Jain M, Krishnamurthy S, Chandra V, Aneja S. Congenital Langerhans cell histiocytosis with skin and lung involvement: Spontaneous regression. The Indian Journal of Pediatrics 2010; 77(7):811-2. https://doi.org/10.1007/s12098-010-01043

PMid: 20589477 